hands of the War Department is to be plainly seen in the collections of what are merely regarded as useless eccentricities at Woolwich and Shoeburyness, but it is very improbable that most of the lessons to be learnt from these have ever been appreciated by those who were responsible for their rejection. Has it not taken twenty years for the system invented by Robert Mallet of building up a massive piece of ordnance capable of being taken to pieces to facilitate transport, to at length bring forth the present seven-pounder screw gun, which can be carried in halves on the backs of mules? It would be interesting to know whether any private firm in this country, if they had received the order, could have manufactured and proved a train of siege guns on similar principles, and capable of as easy transport as the modern field gun, and which would have considerably facilitated Gen. Stewart's advance to Cabul.

It can of course be urged with some show of reason that, considering the enormous supply of most patterns of guns and the vast quantity of ammunition required throughout the Empire, great inconvenience would result from too great a multiplicity of designs; but to continue the manufacture of an inferior pattern for this reason when a better one is procurable appears to us only to make the evil greater when the former has to be finally abandoned as obsolete. Thus we suppose it must have been obvious to a great many persons for the last five years that the days of heavy muzzle-loading guns for the navy were numbered, from the difficulty or impossibility of giving sufficient length of bore for the consumption of large charges of powder while still enabling the gun to be fought in a turret. All possible ingenuity was then expended on shortening the recoil and on mechanical systems of loading in a confined space, with results that might have been incalculably disastrous had this country been involved in war previous to the terrible accident on board the Thunderer; all this too while we believe a suitable pattern of breech-loader was in the hands of a private firm and had been tendered by them for adoption by the War Department. If it could be shown that a Government factory could alone turn out guns of the best manufacture, superior to anything that could be produced by private establishments, the logical sequence would be that armour plates and marine engines and the ships themselves should all be provided in the same way.

The effect of a Government monopoly on the foreign trade of a manufacturer is too well known to require demonstration; but if the encouragement of private establishments for the production of all kinds of arms and warlike stores should result, as it doubtless would, in a larger trade with foreign powers in these manufactures, while we should profit by their custom in time of peace, they would not only find themselves in the event of war with this country cut off from their supply of fresh arms and ammunition, but the whole of our own increased production would be available for national defence.

If such an inquiry as is sought for in this petition be instituted by the present Government, conducted not only by officers of the army and navy, but also under independent scientific advice, we believe that numerous articles of belief and revered principles of construction will be shown to have been long exploded and will have to be at once abandoned. We shall then probably find the Woolwich system of rifling with increasing pitch and studded projectiles giving place to the poly-groove of uniform pitch with rotation by gas-check which has been under consideration for years, and is yet scarcely recognised ; we may even take a hint from the Chinese Government, who, by applying to Sir William Armstrong's firm, have for more than a year been in possession of four more powerful guns than any afloat in our most recent ironclads; we should perhaps find that a system of breech-loading is ready for adoption solving most of the difficulties of turret and casemate defence, and that a trustworthy type of hammered steel is ready at hand to be substituted for the welded coils of wrought iron at present in use.

If it should be found that our Government establishments have been suffering from a slow process of crystallisation, they might be resuscitated by being placed in keen competition with private firms whose very existence depends on their unceasing activity, or at the least it would be ascertained whether in a critical time the country would have to depend entirely on the Royal Gun Factory, or whether some of the old firms who in former years fought so hard for a share in the work have not forgotten their skill.

\section{LIVING ON WATER}

H OW long a man can live on water alone is now the subject of an experiment in New York. A Dr.

Tanner from Minnesota is devoting himself to this trial. Tanner declares that he can live for forty days without food, and is proving, or trying to prove, the truth of the hypothesis on his own unfortunate person. He is reported to have got through twenty-eight days of his endeavour, and still to be alive and comparatively well. On the twentieth day his pulse was 76 , his temperature 98.405 , and his actual weight 132 lbs. On the twentyeighth day his weight was 130 lbs. He lost $27 \frac{1}{2}$ lbs. in the first nineteen days during which he fasted, and then ceased to waste at the same rate. The latest report we have of him states that he is cheerful, active, and, notwithstanding abundant medical opinion to the contrary, confident that he should continue to the end of the time named for the experiment. Of food of the solid kind he touches none ; of drink he partakes of water and nothing else; water and air will, he maintains, sustain him; and that notwithstanding exertions from riding and other exercises. Dr. Tanner is not original in this mode of attempt upon his own life. In the Transactions of the Albany Institute for 1830 Dr. McNaughton reported the history of a man named Reuben Kelsey, who on July 2, I829, declined eating altogether, assigning as a reason "that when it was the will of the Almighty that he should eat he would be furnished with an appetite." McNaughton's account of this man is singularly interesting. We have not room for all the details, but it may be told in brief that Kelsey continued to live for fifty-three days; that he went out of doors and walked about during the greater part of the time, and that he was able to sit up in bed until the last day of his life. During the first three weeks of his abstinence he fell away very fast, but afterwards did not seem to waste so sensibly. Towards the close of his days the colour of his flesh was blue, and at last blackish. His skin was cold, and he complained of chilliness. His general appearance was so ghastly that children were afraid of him. Of this he himself seemed to be aware, for it was not uncommon to observe him covering his face when strangers were passing by. At the time of his deatb Mr. Kelsey was twentyseven years of age. The writer of this notice once attended a gentleman, who, for a nearly similar reason as that assigned by Mr. Kelsey, abstained from all food, except water, for even a longer period, viz., fifty-five days. In this instance the wasting was most obscrved in the first three weeks of the fasting. From this it will be gathered that Dr. Tanner may live to the full extent of forty days on water without being suspected of having been the subject of a miracle. It is against the success of his experiment that he should be exposed to an amount of excitement and vexation that must reduce greatly the vital power, but for all that he may possibly survive the ordeal. The grand question is how he will cry back again. The facts of these examples, painful as they are, are not without their use. They indicate that water being admitted into the body, life may go on for periods 
far beyond any that might be expected, and they expose altogether the fallacy about the value of alcohol when with large quantities of water it has been administered as a supposed life-sustaining food.

\section{B. W. R.}

\section{WATERFOWL ${ }^{1}$}

$\mathrm{NE}$ of the principal objects of these lectures being the illustration of the animals exhibited in the Society's Gardens, I have selected for my address to you this day the subject of "Waterfowl," by which I mean the Anseres, or family Anatida, of naturalists, commonly known as ducks, geese, and swans. Three familiar species of domestic birds, the names of which I have just cited, belong to this family, and have been known to us since the times of the Romans, and a fourth, the Muscovy duck, has been added to the series since the discovery of America. Besides these four domestic species nearly all waterfowl show great aptitude for semi-domestication. When pinioned and put in small ponds, and supplied with food and shelter, most of them will thrive, and many of them will breed in captivity.

The acquisition of waterfowl has long been a subject of special interest to this Society. In 1830, in the first list of our animals ever published, I find thirty species of waterfowl included, amongst which are the Orinoco goose, Mandarin duck, and the Cercopsis goose. In I844 I find twenty-six species included in the catalogue of the animals then living in the Gardens. About that time the thirteenth Earl of Derby, then president of this Society, was the great patron of waterfowl, and, by means of collectors and agents in all parts of the world, brought together in his celebrated menagerie at Knowsley one of the finest collection of these birds ever made. At the disposal of the Knowsley menagerie by auction in $185 x$, examples of 51 different species of waterfowl were sold, many of which had been bred in the Knowsley Gardens.

Since that period the Zoological Society, having become the possessor of some of the choicest specimens sold at Knowsley, has taken up the subject of waterfowl with increased vigour, and has succeeded in adding considerably to the list of introduced species. During the past twenty years there have been exhibited in the Society's Gardens examples of 86 species of this group of birds, and at the present time the collection consists of not less than 270 individuals, referable to 53 different species, forming, as we believe, the finest living series of these birds now in existence. The zoological gardens of Amsterdam, Antwerp, and Berlin, and the Jardin d'Acclimatation of Paris have also excellent collections of waterfowl, and have succeeded in breeding some species which have obstinately refused to avail themselves of the inducements we have offered them in these Gardens. But in extent and variety I believe our series remains pre-eminent.

The total number of species of the family Anatidæ at present recognised by naturalists is about 175 ; of these some 94 , or more than half, have been at various times represented by specimens held in captivity either in our Gardens or elsewhere, and of the species thus exhibited no less than 50 have paired and produced young.

of the nine groups or sub-families into which, as will be seen by the Table, the Anatidæ are divisible, the Anatine or geese, swans, and river-ducks show the greatest aptitude for this kind of semi-domestication. The sea-ducks, lake-ducks, torrent-ducks, and mergansers are much more wild in their nature, and do not thrive nearly so well in confinement. Of the $3 \mathrm{I}$ known species of sea-ducks (Fuligulince) but I 3 are known to have been exhibited in zoological gardens, and of these only 5 have reproduced in captivity. None of the

I Abstract of a "Davis Lecture" given before the Z১ological Society of London, July 8, T880, by P. I. Sclater, F.R.S.. Secretary to the Society. lake-ducks (Erismaturina) or torrent-ducks (Merganet$\operatorname{tin} c$ ) have ever been introduced alive, and none of the Mergansers (Mergine) have been bred in captivity,

\begin{tabular}{|c|c|c|c|c|c|c|c|c|c|}
\hline \multirow[b]{3}{*}{ x. Anseranatinæ } & \multicolumn{5}{|c|}{ Table of Water-fowl } & \multicolumn{2}{|c|}{ Species } & \\
\hline & & \multicolumn{3}{|c|}{ Known. } & \multicolumn{3}{|c|}{ Exhibited. } & & Bred. \\
\hline & $\cdots$ & $\ldots$ & I & $\ldots$ & $\ldots$ & I & $\cdots$ & $\ldots$ & - \\
\hline 2. Cercopsinæ & $\ldots$ & $\ldots$ & I & $\ldots$ & $\ldots$ & $\mathbf{I}$ & $\ldots$ & $\ldots$ & $\mathbf{x}$ \\
\hline 3. Anserinæ ... & $\ldots$ & $\cdots$ & 38 & $\ldots$ & $\ldots$ & 25 & $\ldots$ & $\cdots$ & I 4 \\
\hline 4. Cygninæ $\quad \ldots$ & $\ldots$ & $\ldots$ & Io & $\ldots$ & $\cdots$ & 8 & $\ldots$ & $\ldots$ & 5 \\
\hline 5. Anatinæ & $\ldots$ & $\ldots$ & 75 & $\ldots$ & $\cdots$ & 43 & $\cdots$ & $\cdots$ & 25 \\
\hline 6. Fuligulinæ ... & $\ldots$ & $\ldots$ & $3 \mathbf{I}$ & $\ldots$ & $\ldots$ & I3 & $\ldots$ & $\ldots$ & 5 \\
\hline 7. Erismaturinæ & $\cdots$ & $\cdots$ & 9 & $\cdots$ & $\cdots$ & - & $\ldots$ & $\ldots$ & - \\
\hline 8. Merganettinæ & $\cdots$ & $\ldots$ & 3 & $\ldots$ & $\ldots$ & - & $\ldots$ & $\cdots$ & - \\
\hline 9. Merginæ & $\cdots$ & $\cdots$ & 6 & $\cdots$ & $\cdots$ & 3 & $\cdots$ & $\cdots$ & - \\
\hline & & & 84 & & & 94 & $\cdots$ & $\cdots$ & $5^{\circ}$ \\
\hline
\end{tabular}

although examples of three species of the last-named group have been occasionally exhibited.

Of the geese (Anserina), on the other hand, which number some 38 known species, no less than 25 have been introduced at various times, and of these 14 have reproduced in captivity. Amongst these one of the best introductions effected by the Society is that of the Magellanic or upland goose, of which examples were first received in 1857, presented by Capt. Thomas Moore, at that time Governor of the Falkland Islands, in which settlement, as we know from no less an authority than that of $\mathbf{M r}$. Darwin, the upland goose is a familiar species. The upland goose commenced to breed with us in 1863 , and has continued to do so with tolerable regularity ever since; it has also hybridised in this country with the closely-allied form from Chili, which has been called Bernicla dispar, and of which many examples have been received by the Society in recent years.

Besides the upland goose, the allied ruddy-headed and ashy-headed geese of Antarctic America have been acquired and successfully bred. The ruddy-headed goose has unfortunately been lost, and requires reintroduction, but its ashy-headed brother remains a denizen both of these Gardens and also of similar establishments on the Continent.

Passing on to the swans, we find that a still greater degree of success has been obtained in the acclimatisation of these birds. Ten species of swans are recognised by naturalists, of which eight have been introduced into zoological gardens and five have been bred in captivity. Besides the common tame swan which is upon every piece of water, the ponds of our Gardens contain at the present time examples of the hooper, Bewick's swan, trumpeter swan, black swan, and black-necked swan, and but a short time ago we had also examples of the beautiful Coscoroba swan of Antarctic America, remarkable for its coral-red bill. Of all these the most engaging is perhaps the black-necked swan, originally obtained by the late Lord Derby from Chili, and first acquired by this Society at the dispersal of the Knowsley collection in $185 \mathrm{I}$. A pair of these tbirds first bred with us in 1857 , and the species has continued to do so with more or less regularity ever since that date.

The river-ducks (Anatina), which succeed the swans in the natural series, are the most numerous group of the family. Of the seventy-five known species of river ducks forty-three have been introduced into captivity, and twenty-five have been successfully bred. Of these I will call particular attention to two which have been recently added to the list of introduced species, and are charming representatives of the group.

The rosy-billed duck of South America was first introduced by this Society from Chili in 1867 , but only, unfortunately, in the shape of a single male. In 1870, however, we obtained examples of both sexes from the same locality, which began to breed with us in 1873 . Since then young ones have been batched nearly every 